\title{
Correction
}

\section{Correction to: An innovative approach to integrate unequal protection-based steganography and progressive transmission of physiological data}

\author{
Neerja Sahu ${ }^{1}$ (D) $\cdot$ Dongming Peng ${ }^{1} \cdot$ Hamid Sharif ${ }^{1}$
}

Published online: 15 May 2020

(c) Springer Nature Switzerland AG 2020

\section{Correction to: SN Applied Sciences (2020) 2:237 \\ https://doi.org/10.1007/s42452-020-1992-0}

There was an error in Eq. 15 in the original publication. The term $|C(k)|$ should have been in the denominator.

Publisher's Note Springer Nature remains neutral with regard to jurisdictional claims in published maps and institutional affiliations.

The original article can be found online at https://doi.org/10.1007/s42452-020-1992-0.

Neerja Sahu, neerja.sahu@huskers.unl.edu; Dongming Peng, dpeng2@unl.edu; Hamid Sharif, hsharif@unl.edu|'Department of Electrical and Computer Engineering, University of Nebraska-Lincoln, Lincoln, NE, USA. 